\title{
Public-private relation in the Brazilian policy of tertiary care for cardiovascular conditions
}

\author{
Petter Ricardo de Oliveira 1 \\ Mariana Guerra 2 \\ Adalmir de Oliveira Gomes ${ }^{3}$ \\ Aiane Luiz Martins ${ }^{4}$ \\ 1 Universidade de Brasília, Brasília / DF - Brazil \\ 2 Universidade de Brasília / Programa de Pós-Graduação em Contabilidade, Brasília / DF - Brazil \\ 3 Universidade de Brasília / Programa de Pós-Graduação em Administração, Brasília / DF - Brazil \\ ${ }^{4}$ Instituto Euro Americano de Educação, Ciência e Tecnologia, Brasília / DF - Brazil
}

Specialized health care in Brazil has been provided by the private sector under public regulation and financing since the 1950s. It continued after the promulgation of the 1988 Federal Constitution, which also created the Unified Health System (SUS). In the last decades, the share of the private sector has increased in tertiary care, including cardiovascular services, generating changes in SUS. This study analyzes the public-private relationship in the National Tertiary Care Policy for Cardiovascular Conditions from 2008 to 2014. The results indicate that, compared to the public sector, the private sector has a greater share in both tertiary care for cardiovascular conditions and receivables for providing health services. This points to a contradiction in the management of the health system in Brazil, which, albeit public, all-population-oriented, and free in its conception, has privileged the private sector.

Keywords: cardiovascular service; tertiary care; public policy; public-private relationship.

\section{Relação público-privada na política brasileira de atenção cardiovascular de alta complexidade}

A saúde especializada no Brasil é oferecida pelo setor privado sob regulamentação e financiamento públicos desde a década de 1950, mantendo-se após a promulgação da Constituição Federal de 1988, quando foi criado o Sistema Único de Saúde (SUS). Nas últimas décadas a participação do setor privado aumentou no atendimento terciário, inclusive nos serviços cardiovasculares, gerando mudanças no SUS. Este estudo analisa a relação público-privada na Política Nacional de Atenção Cardiovascular de Alta Complexidade de 2008 a 2014. Os resultados indicam que, comparativamente ao setor público, o setor privado responde por uma maior participação tanto no atendimento terciário para condições cardiovasculares quanto no recebimento de recursos para o fornecimento de serviços de saúde. Isso aponta para uma contradição na gestão do sistema de saúde no Brasil, que, apesar de público, universal e livre, tem privilegiado o setor privado.

Palavras-chave: serviço cardiovascular; cuidado terciário; políticas públicas; relações público-privadas.

\section{Relación público-privada en la política brasileña de atención cardiovascular de alta complejidad}

La salud especializada en Brasil es ofrecida por el sector privado bajo regulación y financiamiento públicos desde la década de 1950, y se mantuvo después de la promulgación de la Constitución Federal de 1988, cuando se creó el Sistema Único de Salud (SUS). En las últimas décadas, la participación del sector privado aumentó en la atención terciaria, incluso en los servicios cardiovasculares, generando cambios en el SUS. Este estudio analiza la relación público-privada en la Política Nacional de Atención Cardiovascular de Alta Complejidad de 2008 a 2014. Los resultados indican que, en comparación con el sector público, el sector privado tiene una mayor participación tanto en la atención terciaria para condiciones cardiovasculares como en la recepción de recursos para prestación de servicios de salud. Esto indica una contradicción en la gestión del sistema de salud en Brasil, pues, a pesar de ser público, universal y libre en su concepción, privilegia al sector privado.

Palabras clave: servicio cardiovascular; cuidado terciario; política públicas; relación público-privada.

DÖ: http://dx.doi.org/10.1590/0034-761220170179x

Article received on May 30, 2017 and accepted on May 3, 2019

[Original version]

The authors are thankful to Igor Antonio Lourenco da Silva (UFU) for his thorough revision and translation of this article. 


\section{INTRODUCTION}

Non-reportable chronic diseases are the major health problem faced by the world population nowadays. In Brazil, it is estimated that $73 \%$ of deaths are caused by such diseases, the most prevalent one being cardiovascular diseases (30\%), neoplasias (16\%), chronic respiratory diseases (6\%), and diabetes mellitus (5\%) (Malta et al., 2014).

The Brazilian public health system has organized networks to provide cardiovascular care through health promotion, prevention of injuries and assistance to those who need secondary and tertiary care (Mendes, 2011). However, the public health sector, historically unable to meet all demands, has constantly resorted to private organizations to provide healthcare to the Brazilian population (Romano \& Scatena, 2014). Since the 1950s, and even after the promulgation of the 1988 Federal Constitution, which created the Unified Health System (SUS - acronym in Portuguese), specialized healthcare has contradictorily been provided in the country by the private sector under public regulation and financing (Solla \& Chioro, 2014). Such contradiction requires a deeper understanding of the publicprivate relationship ${ }^{1}$ between the Brazilian State and private health providers.

This study focuses on the National Policy of Tertiary Care for Cardiovascular Conditions (PNACAC - acronym in Portuguese) to tap into the public-private relationship. The empirical study was performed using secondary data from 2008 through 2014, retrieved from governmental databases. One of the premises of the study is that the interests of public and private players are different and even competing: while the Brazilian State has the public interest as its guiding principles (Alexandrino \& Paulo, 2013), the private sector usually aims at financial profit. Besides, the relationship between the State and private organizations should be scrutinized to ensure all-population-oriented healthcare at all levels within the Brazilian health system.

Some studies (Romano \& Scatena, 2014; Solla \& Chioro, 2014) have pointed out the effects of increasing private engagement in the provision of tertiary care in Brazil. For example, Romano and Scatena (2014) highlight increased promptness and problem solving, expanded service network, reduced waiting times for surgery, and better recovery results as the major strengths of such engagement. In contrast, Solla and Chioro (2014) point to problems related to the private organizations' choice to perform cost-intensive procedures.

The provision of health services has been extended to the private sector within a system that is actually supposed to provide comprehensive, all-population-oriented healthcare, with the State still being the guardian of the public interests and repressor of the demand. In other words, the State can commission the private sector to provide services that the State itself cannot, but the State is not allowed to outsource the provision of the entire demand - even if the demand for public healthcare is larger than the governmental provision of services - as the 1988 Federal Constitution establishes a Unified Health System that is public, comprehensive and all-population-oriented. As such, healthcare is a field that needs strong intervention of both society and the State (Gadelha, Quental, \& Fialho, 2003; Gadelha, 2012; Ribeiro, Moreira, Ouverney, \& Silva, 2017).

\footnotetext{
${ }^{1}$ The public-private relationship is a system of licensing, transfer of financial resources and regulation exercised by public entities (federation, federal states, federal district, and municipalities) in their engagement with private providers of secondary and tertiary care.
} 
According to Mello et al. (2017), rather than a simple case of coexistence, the interdependence between State and market is a common characteristic of SUS. It is consensual that the public manager's is uncapable of regulating the commissioned private sector, whose strong influence is a reflection of its installed capacity. However, the authors contend, there is no country-defined pattern, with some regions being more or less dependent on the private sector. The literature seems to be still lacking a descriptive, longitudinal study on such pattern when it comes to tertiary care in general and cardiovascular care in particular (Marchildon, 2015; Oliver, Lorenc, \& Innvær, 2014).

This study focuses on the provision of health services while assuming that the healthcare needs cannot be predicted because they are irregular (Arrow, 1963; Grossman, 1972). The provision of services is often insufficient to meet all demand, but there are cases in which the provision is greater than the need. In addition, the study focuses on the organizational dimension of Giovanella and Fleury Model (Giovanella \& Fleury, 1995) and discusses provision as a way of ensuring access within the geographical limits of each social territory (Assis \& Jesus, 2012; Thiede \& McIntyre, 2008).

\section{REVIEW OF THE LITERATURE}

\subsection{The National Policy of Tertiary Care for Cardiovascular Conditions (PNACAC)}

According to SUS guidelines, the National Policy of Tertiary Care for Cardiovascular Conditions (PNACAC) is aimed to ensure the principles of public health in Brazil. One of such principles is universality (all-population-orientation), i.e., the entire population shall have access to all healthcare services, including comprehensive, specialized care for cardiovascular conditions. Services shall include humane care actions for prevention of diseases, promotion of health and rehabilitation, as well as diagnostic and surgical procedures. Another principle is decentralization: the policy regionalizes the services following demographics and healthcare networks established according to the population's needs (Pinto, Fraga, \& Freitas, 2012; Ribeiro et al., 2017).

The PNACAC hierarchically organizes specialized cardiovascular care in networks that are planned conjointly by health departments in the federal states and in the municipalities. Such healthcare networks are organizational arrangements of health actions and services, with different technology intensities, established to ensure comprehensive care through technical, logistical and management support systems (Portaria GM/MS n. 4.279, 2010). The PNACAC organizes the sector into six types of services, with their respective minimum annual production, namely: cardiovascular surgeries (180 procedures/year); interventional cardiology procedures (144 procedures/year); pediatric cardiovascular surgeries (120 procedures/year); vascular surgeries (90 procedures/year); extracardiac/endovascular procedures (120 procedures/year); and electrophysiological studies (39 procedures/year).

The PNACAC also establishes licensing requirements for providers of tertiary care for cardiovascular conditions. Such requirements, however, do not rely on regional/local demands, but rather focus on installed capacity and number of procedures (Portaria SAS/MS n. 433, 2012). This has led to the 
concentration of tertiary care providers in large urban centers (Solla \& Chioro, 2014). Eventually, primary healthcare has been available in a "nearly universal" basis to the population, with inadequate referral to specialized care centers despite the principles of decentralization and comprehensiveness (Barata, Tanaka, \& Mendes, 2004). In this context, it is fundamental to investigate the effects of biases in public policies of tertiary care towards the private sector. As Ribeiro and Alcoforado (2016) corroborate, the advantages of governance and agreement in the implementation of policies should be evaluated in each case.

\subsection{Financing of Tertiary Care Within SUS}

Tertiary care can solve approximately 5\% of the population's health problems, but it is the most expensive level of care in the Brazilian public health system, consuming nearly 50\% of the Ministry of Health's expenditures in public health actions and services (Servo, Piola, Paiva, \& Ribeiro, 2011). The reason for such high costs is in the characteristics of tertiary care, which is technology-intensive and requires highly specialized professionals (Solla \& Chioro, 2014).

Tertiary care has been provided within SUS predominantly by the private sector and public university hospitals. The financing of health actions is typical of the liberal model, with mixed engagement of both public and private sectors (Ugá, Porto, \& Piola, 2014). However, the State is still the largest funder of both primary care and tertiary care in referral hospitals and operates at both ends of the healthcare continuum. The share of public resources invested in the private sector is larger than the direct public expenditures on tertiary care in Brazil, especially in regions in poorer socioeconomic and sanitary conditions. This is the case of Northern and Northeastern Brazil, where private health insureds increasingly resorted to SUS-licensed or SUS-funded organizations from 1998 to 2008 (Porto, Ugá, \& Moreira, 2011). This paper contributes to the description and reflection on the provision of services by these organizations (SUS-licensed or SUS-funded), especially for tertiary procedures for cardiovascular conditions.

Up to 2007, the financing of specialized care consisted of directly paying the provider (hospital) for each procedure performed (Solla \& Chioro, 2014). However, Ordinance GM/MS No. 204, as of 29 January 2007, established that federal resources shall be transferred in a single and specific account to the federal states, federal district and municipalities in the form of financing clusters, each constituted by specific components (Portaria GM/MS n. 204, 2007).

The secondary and tertiary care cluster for inpatient and outpatient care has two components: Financial Ceiling of Tertiary Care (MAC - acronym in Portuguese), and Fund for Strategic Actions and Compensation (FAEC - acronym in Portuguese). In the MAC component, federal resources are transferred from the National Health Fund to Health Funds in the federal states, federal district and municipalities, according to an Agreed and Integrated Program (PPI - acronym in Portuguese). MAC resources are incorporated into the fund of the respective entity and transferred regularly. The second component, FAEC, was initially created to cover tertiary, cost-intensive procedures, and it shall be incorporated into MAC for regular transfers with the support of a historical series. At present, all SUS-funded tertiary care procedures in cardiology are funded with MAC resources.

However, despite MAC and FAEC ceilings for secondary and tertiary care, these components have not satisfactorily modified the provision of SUS services for secondary and tertiary care. Thus, the 
logic of paying by procedure, even if indirectly, remains in force in the financing of public health in Brazil (Solla \& Chioro, 2014). In this sense, this paper also contributes to describing the provision of services by the public sector or by SUS-licensed and SUS-funded organizations, especially for tertiary procedures for cardiovascular conditions.

\section{METHOD}

The present study focuses on the provision of health services by drawing the organizational dimension in Giovanella and Fleury Model (Giovanella \& Fleury, 1995). This study discusses supply as a way of ensuring access within the geographical limits of each social territory (Assis \& Jesus, 2012; Thiede \& McIntyre, 2008; Travassos \& Martins, 2004).

To assess the public-private relationship for cardiovascular services provided to SUS, data collection targeted type of health center, as well as type and number of cardiovascular procedures performed. Data collection was carried out through the SUS Department of Informatics (DATASUS), which is responsible for the public health information systems in Brazil and provides data from 2008 onwards. Thus, secondary data were collected for a seven-year period from 2008 through 2014. Such data included the number of hospital beds available to perform cardiovascular procedures authorized by the Ministry of Health. Data were analyzed using descriptive statistics. The research was not submitted to any Research Ethics Committee because it is solely based on secondary, public-access data.

The Type of Provider was a variable considered in the survey ${ }^{2}$ of hospitals providing tertiary care for cardiovascular conditions. It included: (1) Public Providers (at federal, federal state, and municipal levels); and 2) Private Providers, further subdivided into a) Non-Profit Organization, b) Philanthropic Organization and c) For-Profit Organizations.

SUS Hospital Information System (SIH / DATASUS - acronym in Portuguese) was used to obtain the following variables: 1) Number of Procedures and 2) Approved Values for hospital services, i.e., how much the public system paid the hospital that provided a given health service. The analysis focused on the surgical procedures for tertiary care related to cardiovascular conditions. The quantity of surgical procedures performed and the values paid to each type of provider (i.e., public or private organization) were compared to assess the differences in financing and provision of tertiary care for cardiovascular conditions.

\section{RESULTS AND DISCUSSION}

Table 1 shows the number of SUS-funded hospitals and beds for cardiovascular surgery by region and by federal state in 2014. In total, 277 hospitals provided 697 surgical services in this period. Tables 1 shows that the Southeast region concentrates nearly half of the hospitals $(\mathrm{N}=125 ; 45 \%)$ and services $(\mathrm{N}=294 ; 42 \%)$ in Brazil, while the Midwest has the lowest numbers.

${ }^{2}$ Data collection was limited to organizations providing services to SUS, as authorized by the Ministry of Health pursuant to Ordinance SAS / MS No. 210/2004. 

CARDIOVASCULAR CONDITIONS BY REGION AND FEDERAL STATE

\begin{tabular}{|c|c|c|c|c|c|c|c|c|}
\hline \multirow{3}{*}{ Region } & \multirow{3}{*}{$\begin{array}{l}\text { Federal } \\
\text { State }\end{array}$} & \multirow{2}{*}{\multicolumn{2}{|c|}{ Total Hospitals }} & \multicolumn{5}{|c|}{ Surgical Beds for Cardiovascular Conditions } \\
\hline & & & & \multicolumn{2}{|c|}{ Total Available } & \multicolumn{2}{|r|}{ sus } & \multirow{2}{*}{$\begin{array}{c}\% \text { SUS/ } \\
\text { Total Available }\end{array}$} \\
\hline & & $\mathrm{N}$ & $\begin{array}{c}\text { \%Region / } \\
\text { \% Brazil }\end{array}$ & $\mathrm{N}$ & $\begin{array}{c}\text { \%Region / } \\
\text { \% Brazil }\end{array}$ & $\mathrm{N}$ & $\begin{array}{c}\text { \%Region / } \\
\text { \% Brazil }\end{array}$ & \\
\hline \multirow{4}{*}{$\begin{array}{l}\text { Midwest } \\
\text { (MW) }\end{array}$} & DF & 2 & 9.0 & 134 & 29.7 & 50 & 20.4 & 37.3 \\
\hline & GO & 11 & 50.0 & 188 & 41.6 & 117 & 47.7 & 62.2 \\
\hline & MS & 4 & 18.1 & 56 & 12.4 & 29 & 11.8 & 51.7 \\
\hline & MT & 5 & 22.7 & 73 & 16.1 & 49 & 20.0 & 67.1 \\
\hline \multirow[t]{4}{*}{ Total MW } & & 22 & $100 / / 7.9$ & 451 & $100 / / 8.1$ & 245 & 100//7.6 & 54.3 \\
\hline & $A L$ & 3 & 5.3 & 73 & 6.7 & 37 & 5.7 & 50.6 \\
\hline & BA & 13 & 23.2 & 276 & 25.5 & 134 & 20.7 & 48.5 \\
\hline & CE & 14 & 25.0 & 188 & 17.3 & 134 & 20.7 & 71.2 \\
\hline \multirow{6}{*}{$\begin{array}{l}\text { Northeast } \\
\text { (NE) }\end{array}$} & MA & 2 & 3.5 & 39 & 3.6 & 22 & 3.4 & 56.4 \\
\hline & PB & 2 & 3.5 & 55 & 5.0 & 44 & 6.8 & 80.0 \\
\hline & PE & 9 & 16.0 & 248 & 22.9 & 173 & 26.7 & 69.7 \\
\hline & $\mathrm{Pl}$ & 5 & 8.9 & 47 & 4.3 & 35 & 5.4 & 74.4 \\
\hline & RN & 5 & 8.9 & 110 & 10.1 & 46 & 7.1 & 41.8 \\
\hline & SE & 3 & 5.3 & 45 & 4.1 & 22 & 3.4 & 48.8 \\
\hline \multirow[t]{4}{*}{ Total NE } & & 56 & $100 / / 20.2$ & 1081 & $100 / / 19.5$ & 647 & $100 / / 20.2$ & 59.8 \\
\hline & $A C$ & 1 & 7.1 & 3 & 0.6 & 3 & 1.1 & 100 \\
\hline & AM & 4 & 28.5 & 71 & 15.5 & 37 & 14.2 & 52.1 \\
\hline & $A P$ & 1 & 7.1 & 151 & 33.0 & 115 & 44.2 & 76.1 \\
\hline \multirow[t]{4}{*}{ North (N) } & PA & 4 & 28.5 & 179 & 39.1 & 71 & 27.3 & 39.6 \\
\hline & RO & 1 & 7.1 & 21 & 4.6 & 8 & 3.0 & 38.1 \\
\hline & $\mathrm{RR}$ & 0 & - & 10 & 2.1 & 10 & 3.8 & 100 \\
\hline & TO & 3 & 21.4 & 22 & 4.8 & 16 & 6.1 & 72.7 \\
\hline \multirow[t]{2}{*}{ Total N } & & 14 & $100 / / 5.0$ & 457 & $100 / / 8.2$ & 260 & $100 / / 8.1$ & 56.8 \\
\hline & ES & 7 & 5.6 & 80 & 3.3 & 48 & 3.5 & 60.0 \\
\hline \multirow{3}{*}{$\begin{array}{l}\text { Southeast } \\
\text { (SE) }\end{array}$} & $M G$ & 39 & 31.2 & 541 & 22.6 & 308 & 22.5 & 56.9 \\
\hline & RJ & 24 & 19.2 & 641 & 26.8 & 323 & 23.6 & 50.3 \\
\hline & SP & 55 & 44.0 & 1128 & 47.2 & 686 & 50.2 & 60.8 \\
\hline \multirow[t]{2}{*}{ Total SE } & & 125 & $100 / / 45.1$ & 2390 & $100 / / 43.2$ & 1365 & $100 / / 42.6$ & 57.1 \\
\hline & PR & 26 & 43.3 & 403 & 35.1 & 218 & 32.0 & 54.0 \\
\hline \multirow[t]{2}{*}{ South (S) } & RS & 22 & 36.6 & 463 & 40.4 & 267 & 39.2 & 57.6 \\
\hline & SC & 12 & 20.0 & 280 & 24.4 & 196 & 28.7 & 70.0 \\
\hline Total S & & 60 & 100//21.6 & 1146 & $100 / / 20.7$ & 681 & $100 / / 21.2$ & 59.4 \\
\hline TOTAL Brazil & & 277 & 100 & 5525 & 100 & 3198 & 100 & 57.8 \\
\hline
\end{tabular}

Source: Elaborated by the authors.

Note: In 2014, there were no SUS-licensed hospitals in Roraima (RR), but there were surgical beds available in SUS-unlicensed hospitals. 
Table 1 shows that 277 hospitals provided surgical beds for cardiovascular conditions in 2014, and nearly $60 \%$ of those were included in SUS, a percentage that is representative of most regions in the country. Northeast and South were the regions with the greatest number of SUS-funded beds. Only six federal states had more beds available in the public than in the private sector: Federal District (DF), Bahia (BA), Rio Grande do Norte (RN), Sergipe (SE), Pará (PA), and Rondônia (RO). The states of Roraima (RR) and Acre (AC) had 100\% of their surgical beds for cardiovascular conditions available to SUS. In both states, the hospitals with this type of bed are public.

Table 2 shows the tertiary care services for cardiovascular conditions provided in 2014 by the hospitals as authorized by the Ministry of Health by location (region and federal state). Most hospital services in the country correspond to cardiovascular and interventional surgeries (CIS) $(\mathrm{N}=231$; $33 \%)$ and vascular surgeries (VS) $(\mathrm{N}=207 ; 29 \%)$. In an intermediate position are extracardiac/ endovascular procedures (EEP) $(\mathrm{N}=108 ; 15 \%)$ and electrophysiological studies (ES) $(\mathrm{N}=85 ; 12 \%)$. Pediatric cardiovascular surgery (PSC) is the least provided service $(\mathrm{N}=67 ; 9.6 \%)$.

\section{TABLE 2 CARE PROVIDERS FOR CARDIOVASCULAR CONDITIONS AUTHORIZED BY THE MINISTRY OF} HEALTH BY REGION AND FEDERAL STATE

\begin{tabular}{|c|c|c|c|c|c|c|c|c|c|c|c|}
\hline \multirow{2}{*}{ Region } & \multirow{2}{*}{$\begin{array}{l}\text { Federal } \\
\text { State }\end{array}$} & \multicolumn{2}{|c|}{ CIS } & \multicolumn{2}{|c|}{ PSC } & \multicolumn{2}{|c|}{ vS } & \multicolumn{2}{|c|}{ EEP } & \multicolumn{2}{|c|}{ ES } \\
\hline & & $\mathrm{N}$ & $\%$ & $\mathrm{~N}$ & $\%$ & $N$ & $\%$ & N & $\%$ & $\mathrm{~N}$ & $\%$ \\
\hline \multirow{4}{*}{ Midwest (MW) } & DF & 2 & 10.5 & 2 & 40.0 & 2 & 14.2 & 1 & 12.5 & 2 & 22.2 \\
\hline & GO & 9 & 47.3 & 1 & 20.0 & 5 & 35.7 & 2 & 25.0 & 3 & 33.3 \\
\hline & MS & 3 & 15.7 & 1 & 20.0 & 4 & 28.5 & 2 & 25.0 & 1 & 11.1 \\
\hline & MT & 5 & 26.3 & 1 & 20.0 & 3 & 21.4 & 3 & 37.5 & 3 & 33.3 \\
\hline \multirow[t]{5}{*}{ Total MW } & & 19 & 8.2 & 5 & 7.4 & 14 & 6.7 & 8 & 7.4 & 9 & 10.5 \\
\hline & $\mathrm{AL}$ & 3 & 6.3 & 1 & 4.7 & 2 & 5.2 & 2 & 9.0 & 3 & 14.2 \\
\hline & BA & 12 & 25.5 & 7 & 33.3 & 12 & 31.5 & 6 & 27.2 & 5 & 23.8 \\
\hline & CE & 10 & 21.2 & 3 & 14.2 & 6 & 15.7 & 3 & 13.6 & 2 & 9.5 \\
\hline & MA & 2 & 4.2 & 2 & 9.5 & 2 & 5.2 & 1 & 4.5 & 1 & 4.7 \\
\hline \multirow[t]{5}{*}{ Northeast (NE) } & PB & 3 & 6.3 & 0 & - & 3 & 7.8 & 1 & 4.5 & 1 & 4.7 \\
\hline & PE & 8 & 17.0 & 3 & 14.2 & 6 & 15.7 & 5 & 22.7 & 5 & 23.8 \\
\hline & $\mathrm{Pl}$ & 3 & 6.3 & 2 & 9.5 & 4 & 10.5 & 2 & 9.0 & 1 & 4.7 \\
\hline & RN & 5 & 10.6 & 1 & 4.7 & 2 & 5.2 & 1 & 4.5 & 2 & 9.5 \\
\hline & SE & 1 & 2.1 & 2 & 9.5 & 1 & 2.6 & 1 & 4.5 & 1 & 4.7 \\
\hline Total NE & & 47 & 20.3 & 21 & 31.3 & 38 & 18.3 & 22 & 20.3 & 21 & 24.7 \\
\hline
\end{tabular}


RAP | Public-private relation in the Brazilian policy of tertiary care for cardiovascular conditions

\begin{tabular}{|c|c|c|c|c|c|c|c|c|c|c|c|}
\hline \multirow{2}{*}{ Region } & \multirow{2}{*}{$\begin{array}{l}\text { Federal } \\
\text { State }\end{array}$} & \multicolumn{2}{|c|}{ CIS } & \multicolumn{2}{|c|}{ PSC } & \multicolumn{2}{|c|}{ vS } & \multicolumn{2}{|c|}{ EEP } & \multicolumn{2}{|c|}{ ES } \\
\hline & & $\mathrm{N}$ & $\%$ & $\mathrm{~N}$ & $\%$ & $N$ & $\%$ & $\mathrm{~N}$ & $\%$ & $N$ & $\%$ \\
\hline \multirow{7}{*}{$\begin{array}{l}\text { North } \\
\text { (N) }\end{array}$} & $A C$ & 1 & 8.3 & 0 & - & 0 & - & 0 & - & 0 & - \\
\hline & AM & 3 & 25.0 & 0 & - & 2 & 20.0 & 1 & 20.0 & 2 & 40.0 \\
\hline & AP & 1 & 8.3 & 0 & - & 0 & - & 0 & - & 0 & - \\
\hline & PA & 4 & 33.3 & 2 & 100 & 4 & 40.0 & 2 & 40.0 & 2 & 40.0 \\
\hline & RO & 1 & 8.3 & 0 & - & 1 & 10.0 & 1 & 20.0 & 0 & - \\
\hline & $\mathrm{RR}$ & 0 & - & 0 & - & 0 & - & 0 & - & 0 & - \\
\hline & TO & 2 & 16.6 & 0 & - & 3 & 30.0 & 1 & 20.0 & 1 & 20.0 \\
\hline \multirow[t]{2}{*}{ Total N } & & 12 & 5.9 & 2 & 2.9 & 10 & 4.8 & 5 & 4.6 & 5 & 5.8 \\
\hline & ES & 6 & 5.7 & 2 & 7.6 & 6 & 6.5 & 3 & 7.1 & 2 & 6.4 \\
\hline \multirow{3}{*}{ Southeast (SE) } & MG & 32 & 30.7 & 8 & 30.7 & 29 & 31.8 & 16 & 38.1 & 11 & 35.4 \\
\hline & RJ & 20 & 19.2 & 4 & 15.3 & 18 & 19.7 & 6 & 14.2 & 6 & 19.3 \\
\hline & SP & 46 & 44.2 & 12 & 46.1 & 38 & 41.7 & 17 & 40.4 & 12 & 38.7 \\
\hline \multirow[t]{2}{*}{ Total SE } & & 104 & 45.0 & 26 & 38.8 & 91 & 43.9 & 42 & 38.8 & 31 & 36.4 \\
\hline & PR & 22 & 44.9 & 7 & 53.9 & 25 & 46.3 & 12 & 38.7 & 6 & 31.6 \\
\hline \multirow[t]{2}{*}{ South (S) } & RS & 17 & 34.6 & 4 & 30.8 & 20 & 37.0 & 13 & 41.9 & 10 & 52.6 \\
\hline & SC & 10 & 20.4 & 2 & 15.4 & 9 & 16.7 & 6 & 19.4 & 3 & 15.8 \\
\hline Total S & & 49 & 21.2 & 13 & 19.4 & 54 & 26.0 & 31 & 28.7 & 19 & 22.3 \\
\hline TOTAL Brazil & & 231 & 33.0 & 67 & 9.6 & 207 & 29.6 & 108 & 15.4 & 85 & 12.1 \\
\hline
\end{tabular}

Source: Elaborated by the authors.

Note: CIS = cardiovascular and interventional surgeries; PCS = pediatric cardiovascular surgeries; VS = vascular surgeries; $\mathrm{EEP}=$ extracardiac/endovascular procedures; $\mathrm{ES}=$ electrophysiological studies.

Table 2 also shows some healthcare gaps, i.e., some federal states do not feature any provider of tertiary care for cardiovascular conditions or do not provide certain services in the area. The North region provides the lowest number of services in the area, with the following distribution in its federal states: no organizations performing cardiovascular surgeries in the state of Roraima (RR); one hospital performing only cardiovascular and interventional surgeries in each of the states of Acre (AC) and Amapá (AP); no organizations performing pediatric cardiovascular surgeries nor providing electrophysiological studies in the state of Rondônia (RO); and no hospitals performing pediatric cardiovascular surgeries in the states of Amazonas (AM) and Tocantins (TO).

Table 3 shows that $73 \%(\mathrm{~N}=203)$ of the SUS-licensed providers of tertiary care for cardiovascular conditions in 2014 were from the private sector. It comprised philanthropic organizations $(\mathrm{N}=136$; $67 \%)$, for-profit organizations $(\mathrm{N}=43 ; 21 \%)$, and non-profit organizations $(\mathrm{N}=24 ; 12 \%)$. 
RAP $\quad$ Public-private relation in the Brazilian policy of tertiary care for cardiovascular conditions

TABLE 3 SUS-LICENSED ORGANIZATIONS PERFORMING TERTIARY CARE FOR CARDIOVASCULAR CONDITIONS BY REGION AND FEDERAL STATE, ACCORDING TO TYPE OF PROVIDER (2014)

\begin{tabular}{|c|c|c|c|c|c|c|c|c|c|c|c|c|c|}
\hline \multirow[b]{3}{*}{ Region } & \multirow[b]{3}{*}{ State } & \multicolumn{8}{|c|}{ Private Organization } & \multirow{2}{*}{\multicolumn{2}{|c|}{$\begin{array}{l}\text { Total Public } \\
\text { Organization }\end{array}$}} & \multirow{3}{*}{$\begin{array}{c}\% \\
\text { Private }\end{array}$} & \multirow[b]{3}{*}{$\%$ Public } \\
\hline & & \multicolumn{2}{|c|}{ Philanthropic } & \multicolumn{2}{|c|}{ For-profit } & \multicolumn{2}{|c|}{ Non-profit } & \multicolumn{2}{|c|}{$\begin{array}{l}\text { Total Private } \\
\text { Organization }\end{array}$} & & & & \\
\hline & & N & $\%$ & $\mathrm{~N}$ & $\%$ & $\mathrm{~N}$ & $\%$ & $\mathrm{~N}$ & $\%$ & $\mathrm{~N}$ & $\%$ & & \\
\hline \multirow{4}{*}{$\begin{array}{l}\text { Midwest } \\
\text { (MW) }\end{array}$} & $\mathrm{DF}$ & 1 & 8.3 & 0 & - & 0 & - & 1 & 5.8 & 1 & 20.0 & 50.0 & 50.0 \\
\hline & G0 & 3 & 25 & 3 & 100 & 2 & 100 & 8 & 47.0 & 3 & 60.0 & 72.7 & 27.2 \\
\hline & MS & 3 & 25 & 0 & - & 0 & - & 3 & 17.6 & 1 & 20.0 & 75.0 & 25.0 \\
\hline & MT & 4 & 33.3 & 0 & - & 0 & - & 4 & 23.5 & 1 & 20.0 & 80.0 & 20.0 \\
\hline \multirow[t]{4}{*}{ Total MW } & & 11 & 8 & 3 & 6.9 & 2 & 8.3 & 16 & 8.3 & 6 & 8.1 & 72.7 & 27.2 \\
\hline & $\mathrm{AL}$ & 2 & 6.4 & 0 & - & 0 & - & 2 & 4.3 & 1 & 10.0 & 66.6 & 33.3 \\
\hline & BA & 9 & 29 & 2 & 15.3 & 0 & - & 11 & 23.9 & 2 & 20.0 & 84.6 & 15.3 \\
\hline & $\mathrm{CE}$ & 5 & 16.1 & 3 & 23.0 & 1 & 50.0 & 9 & 19.5 & 5 & 50.0 & 64.2 & 35.7 \\
\hline \multirow{6}{*}{$\begin{array}{l}\text { Northeast } \\
\text { (NE) }\end{array}$} & MA & 1 & 3.2 & 1 & 7.6 & 0 & - & 2 & 4.3 & 0 & & 100 & 0.0 \\
\hline & PB & 2 & 6.4 & 1 & 7.6 & 0 & - & 3 & 6.5 & 0 & & 100 & 0.0 \\
\hline & $P E$ & 6 & 19.3 & 3 & 23.0 & 0 & & 9 & 19.5 & 0 & & 100 & 0.0 \\
\hline & $\mathrm{PI}$ & 2 & 6.4 & 1 & 7.6 & 0 & & 3 & 6.5 & 1 & 10.0 & 75.0 & 25.0 \\
\hline & RN & 2 & 6.6 & 1 & 7.6 & 1 & 50.0 & 4 & 8.8 & 1 & & 80.0 & 20.0 \\
\hline & SE & 1 & 3.2 & 1 & 7.6 & 0 & & 2 & 4.3 & 1 & 10.0 & 66.6 & 33.3 \\
\hline \multirow[t]{3}{*}{ Total NE } & & 30 & 22 & 13 & 30.2 & 2 & 8.3 & 45 & 22.0 & 11 & 14.8 & 80.3 & 19.6 \\
\hline & $A C$ & 0 & - & 0 & - & 1 & 25.0 & 1 & 9.0 & 0 & & 100 & 0.0 \\
\hline & AM & 3 & 60 & 0 & - & 1 & 25.0 & 4 & 36.3 & 0 & & 100 & 0.0 \\
\hline \multirow{4}{*}{ North (N) } & $\mathrm{AP}$ & 0 & - & 0 & - & 1 & 25.0 & 1 & 9.0 & 0 & & 100 & 0.0 \\
\hline & PA & 1 & 20 & 2 & 100 & 1 & 25.0 & 4 & 36.3 & 0 & & 100 & 0.0 \\
\hline & RO & 0 & - & 0 & - & 0 & & 0 & & 1 & 33.3 & 0.0 & 100 \\
\hline & TO & 1 & 20 & 0 & - & 1 & 25.0 & 2 & 18.1 & 1 & 33.3 & 66.6 & 33.3 \\
\hline \multirow[t]{2}{*}{ Total N } & & 5 & 3.6 & 2 & 4.6 & 5 & 20.8 & 12 & 5.8 & 2 & 2.7 & 85.7 & 14.2 \\
\hline & ES & 1 & 1.7 & 0 & & 1 & 8.3 & 2 & 2.3 & 4 & 10.5 & 33.3 & 66.6 \\
\hline \multirow{3}{*}{$\begin{array}{l}\text { Southeast } \\
\text { (SE) }\end{array}$} & $M G$ & 21 & 37.5 & 7 & 36.8 & 3 & 25.0 & 31 & 35.6 & 8 & 21.0 & 79.4 & 20.5 \\
\hline & RJ & 11 & 19.6 & 5 & 26.3 & 1 & 8.3 & 17 & 19.5 & 7 & 18.4 & 70.8 & 29.1 \\
\hline & $\mathrm{SP}$ & 23 & 41.0 & 7 & 36.8 & 7 & 58.3 & 37 & 42.5 & 19 & 50.0 & 66.0 & 33.9 \\
\hline \multirow[t]{2}{*}{ Total SE } & & 56 & 41.1 & 19 & 44.1 & 12 & 50 & 87 & 42.6 & 38 & 51.3 & 69.6 & 30.4 \\
\hline & PR & 13 & 38.2 & 3 & 50.0 & 3 & 100 & 19 & 44.1 & 7 & 41.1 & 73.0 & 26.9 \\
\hline \multirow[t]{2}{*}{ South (S) } & $\mathrm{RS}$ & 13 & 38.2 & 2 & 33.3 & 0 & & 15 & 34.8 & 7 & 41.1 & 68.1 & 31.8 \\
\hline & SC & 8 & 23.5 & 1 & 16.6 & 0 & & 9 & 20.9 & 3 & 17.6 & 75.0 & 25.0 \\
\hline Total S & & 34 & 25.0 & 6 & 13.9 & 3 & 12.5 & 43 & 21.0 & 17 & 22.9 & 71.6 & 28.3 \\
\hline TOTAL Bra & & 136 & 67.0 & 43 & 21.1 & 24 & 11.8 & 203 & 100 & 74 & 100 & 73.2 & 26.7 \\
\hline
\end{tabular}

Source: CNES (2014). 
Table 3 also shows the percentages of private organizations providing tertiary care for cardiovascular conditions range from $69 \%$ in the Southeast to $86 \%$ in the North region, clear evidence of the private sector predominance in the provision of these services throughout Brazil. In some federal states, all hospitals providing such services belong to the private sector, namely: Maranhão (MA), Paraíba (PB), and Pernambuco (PE), in the Northeast; Acre (AC), Amazonas (AM), Amapá (AP), and Pará (PA), in the North.

Table 4 reveals the number of SUS licenses by type of provider from 2008 through 2014 . The private sector has the highest rate of increase (over 28\%), reaching 203 hospitals in 2014 from 158 in 2008, while the public sector has 66 and 74 SUS-licensed hospitals in 2008 and 2014, respectively (12\% increase). Philanthropic organizations are the ones with the greatest rate of increase $(22.5 \%)$ in the period. In sum, a trend is apparent in the licensing of private organizations, in prejudice of public organizations. In 2014, the licensing of private hospitals outnumbered that of public hospitals by nearly three times.

\section{TABLE 4 SUS-LICENSED ORGANIZATIONS PROVIDING TERTIARY CARE FOR CARDIOVASCULAR CONDITIONS, BY TYPE OF PROVIDER, IN BRAZIL (2008-2014)}

\begin{tabular}{|c|c|c|c|c|c|c|c|c|c|c|c|c|c|c|c|c|c|}
\hline \multirow{2}{*}{\multicolumn{2}{|c|}{ Type of Provider }} & \multicolumn{2}{|c|}{2008} & \multicolumn{2}{|c|}{2009} & \multicolumn{2}{|c|}{2010} & \multicolumn{2}{|c|}{2011} & \multicolumn{2}{|c|}{2012} & \multicolumn{2}{|c|}{2013} & \multicolumn{2}{|c|}{2014} & \multicolumn{2}{|c|}{$\begin{array}{l}\text { Rate of } \\
\text { Increase }\end{array}$} \\
\hline & & N & $\%$ & N & $\%$ & $\mathrm{~N}$ & $\%$ & N & $\%$ & $\mathrm{~N}$ & $\%$ & N & $\%$ & N & $\%$ & $\mathrm{~N}$ & $\%$ \\
\hline \multirow{3}{*}{ Private } & $\begin{array}{l}\text { Philanthropic } \\
\text { Organization }\end{array}$ & 111 & 70.3 & 115 & 70.1 & 119 & 69.6 & 123 & 69.1 & 127 & 68.3 & 129 & 67.2 & 136 & 67 & 25 & 22.5 \\
\hline & $\begin{array}{c}\text { For-Profit } \\
\text { Organization }\end{array}$ & 35 & 22.2 & 36 & 22 & 38 & 22.2 & 39 & 21.9 & 39 & 21 & 41 & 21.4 & 43 & 21.2 & 8 & 22.8 \\
\hline & $\begin{array}{c}\text { Non-Profit } \\
\text { Organization }\end{array}$ & 12 & 7.59 & 13 & 7.93 & 14 & 8.19 & 16 & 8.99 & 20 & 10.8 & 22 & 11.5 & 24 & 11.8 & 12 & 100 \\
\hline \multicolumn{2}{|c|}{ Private Total } & 158 & 100 & 164 & 100 & 171 & 100 & 178 & 100 & 186 & 100 & 192 & 100 & 203 & 100 & 45 & 28 \\
\hline \multicolumn{2}{|c|}{ Public Organization } & 66 & 100 & 68 & 100 & 68 & 100 & 70 & 100 & 73 & 100 & 73 & 100 & 74 & 100 & 8 & 12 \\
\hline
\end{tabular}

Source: Elaborated by the authors

Table 5 includes the number of tertiary care procedures and financial expenditures (in Brazilian Reais - BRL) for cardiovascular conditions segmented in public and private organizations. Private hospitals have been responsible for 144,584/year (71\%) cardiovascular surgical procedures, which required approximately $72 \%$ (BRL 972,503,672/year) of the funding available for this type of healthcare. Meanwhile, the public sector performed approximately $29 \%(59,020 /$ year $)$ of the procedures and received 27\% (BRL 368,977,148) of the funding. 
RAP | Public-private relation in the Brazilian policy of tertiary care for cardiovascular conditions

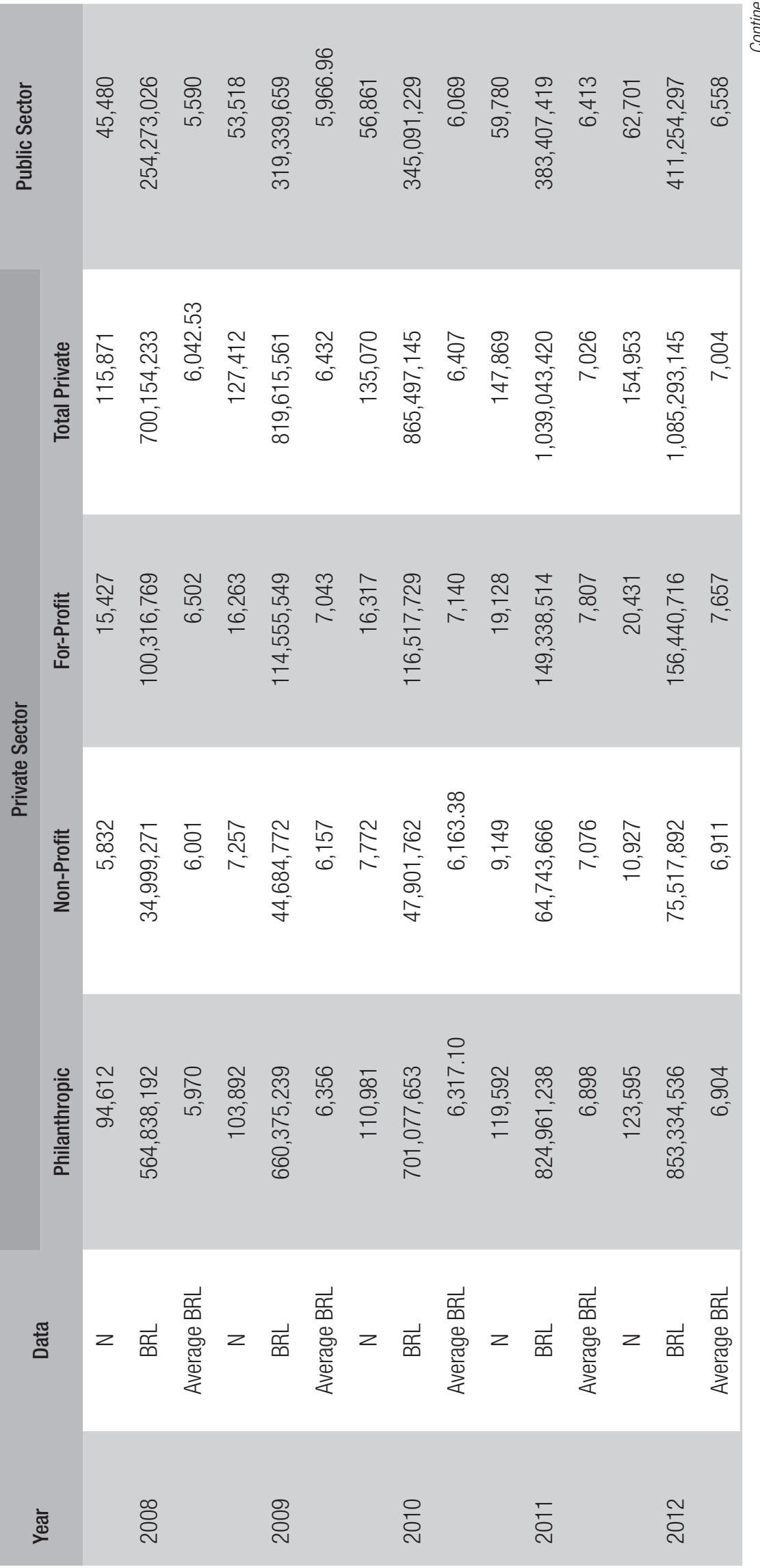

JOURnal of PUblic administration ｜ Rio de Janeiro 53(4):753-768, July - Aug. 2019 
RAP | Public-private relation in the Brazilian policy of tertiary care for cardiovascular conditions

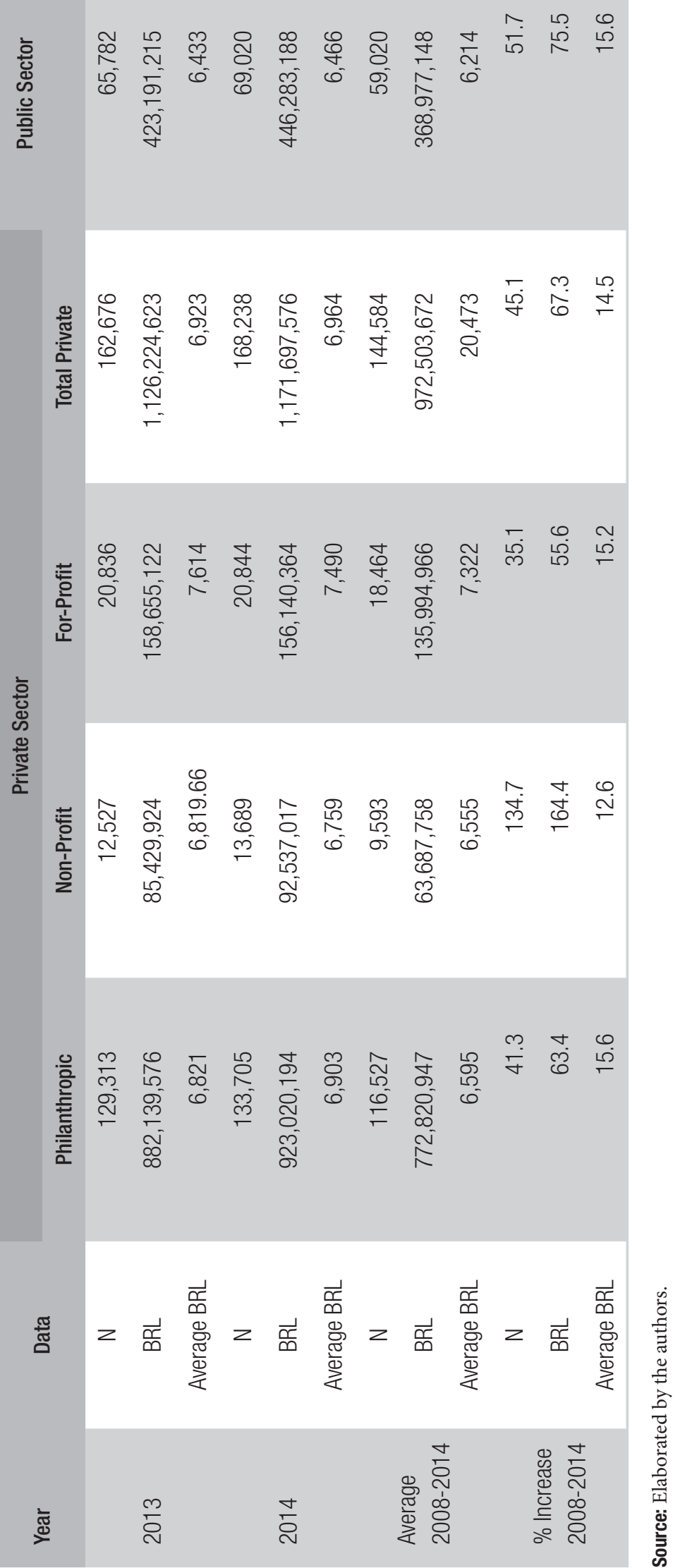

JOURNAL OF PUblic AdMinistration | Rio de Janeiro 53(4):753-768, July - Aug. 2019 
Based on the number of surgical procedures performed from 2008 through 2014 (Table 5), the trend in the provision of tertiary care for cardiovascular conditions in Brazil points to a higher growth in public organizations (52\%; from 45,480 in 2008 to 69,020 in 2014) and a lower growth in private organizations (45\%; from 115,871 in 2008 to 168,238 in 2014). A similar trend is also found for the financial expenditures (Table 5): a higher increase, of approximately 75\%, in the public sector (from BRL 254,273,026 in 2008 to 446,283,188 in 2014), and a lower increase, of approximately $67 \%$, in the private sector (from BRL 700,154,233 in 2008 to 1,171,697,576 in 2014).

Nevertheless, the private organizations have been accountable for the majority of the tertiary care for cardiovascular conditions in Brazil and provided most of the highly cost-intensive procedures. This suggests that tertiary care for cardiovascular conditions has been appealing to the private sector, especially when it comes to cost-intensive procedures, as private and public hospitals have provided procedures that cost nearly BRL 21,000 and 6,300 on average/year, respectively (see Table 5). Thus, healthcare costs have grown excessively and generated a financing logic that favors the most sophisticated, technology-intensive and expensive type of healthcare in prejudice of simpler, noncost-intensive healthcare, however more universal in provision primary care may be.

Such results are evidence that the network of tertiary healthcare for cardiovascular conditions in Brazil is quite extensive and disproportionately distributed throughout the country. Concentrations and gaps were identified in the number of hospitals and cardiovascular surgical beds by location (regions and federal states). While the Southeast region has had the largest concentration of organizations and provided the highest number of cardiovascular services (nearly half of the entire country), the North region has been accountable for less than $6 \%$ of hospitals and services. This can be explained by the fact that these regions are those with the highest and lowest population density and human development index, respectively (Instituto Brasileiro de Geografia e Estatística [IBGE], 2014). The risk of such gaps is in the lack of healthcare for patients in need of cardiovascular surgery. For instance, several studies (e.g., Oram, Buckenham, Roake, \& Lewis, 2008; Turnbull et al., 2000) have shown that late diagnosis, examination and treatment of patients with peripheral obstructive arterial disease lead to increased complications and mortality.

Although SUS has developed its financing strategies for secondary and tertiary care through a model of financing clusters and allows federal state and municipal managers to freely allocate their resources, the practice has been of an indirect financing, with payments made by procedures. This corroborates Mendes (2011) and Solla and Chioro (2014), who pointed to private interests overrunning the real needs of a universal health system. SUS commissions private services through contracts and agreements, which reduces its ability to condition provision to the population's health priorities and needs, since market dynamics follows the logic of supply, rather than that of demand. Thus, prices can be arbitrary, and supply can rely solely on those procedures that the private provider decides to provide. 


\section{FINAL REMARKS}

SUS was established in 1988 as a right of all citizens (i.e., a universal system) and the State's duty to provide free and comprehensive healthcare at all levels of complexity. The engagement of the private sector in SUS was theoretically allowed as a complement to provide care under public financing. However, private hospitals have increasingly provided secondary and tertiary care, which has increased the allocation of public resources to private hospitals.

The present study specifically demonstrates that the private share in tertiary care for cardiovascular conditions in Brazil does not follow a logic of complementarity, with an increasing predominance of the private sector. Private organizations have received higher payments for specialized care than the public sector, as they provide services that are costlier to the state. The public structure of specialized healthcare in Brazil is insufficient to comply with SUS universality and comprehensiveness principles (Solla \& Chioro, 2014). This seems to have led to the increased share of the private sector in the provision of specialized care services for cardiovascular conditions.

As discussed by Santos (2010), treating the public-private relationship as two competing poles does not seem to help improve the management of tertiary care in Brazil. On the contrary, such poles should be seen as partners in the implementation of SUS principles. Therefore, as proposed by Mendes (2011), it is necessary to conceive of management strategies that seek to organize the network of secondary and tertiary healthcare hand in hand with the primary care in health organizations in different locations. Guerra and Gonçalves (2014) argue hospital beds for tertiary care should be made available to any individual, regardless of the municipality or state they reside. Another important step is to increase regulatory control over the provision and payment of tertiary care procedures to avoid illegal, one-sided or harmful contracts and agreements. In addition, the SUS licensing logic, based on the private sector's service provision, is also problematic to the system. Thus, SUS should opt for a logic of required demand, rather than that of supply determined by the private sector.

One possibility to rationalize the way of financing tertiary healthcare is adopting the capitalist logic of resource allocation. This logic considers: 1) the segmentation of health services by the level of healthcare; 2) the healthcare demands as a proxy of the population's health conditions; and 3) the structuring of hospitals providing tertiary care through integrated care networks (Guerra \& Gonçalves, 2014).

Given the importance of gaining more insight into the public-private relationship for secondary and tertiary care in the Brazilian public health system, further studies should also investigate the impact of the performance of hospitals providing tertiary care both on the patients' recovery and on the use of the resources that are passed on by the public administration. This analysis could be included as a PNANAC criterion, also assisting the State in directing hospital organizations in places where there is reduced availability of beds. This and other guidelines make up the current discussion paper on health governance (OECD, 2010). 


\section{REFERENCES}

Alexandrino, M.; Paulo, V. (2000). Direito Administrativo descomplicado (21a ed.). Rio de Janeiro: Forense, São Paulo, SP: Método.

Arrow, K. (1963). Uncertainty and the welfare economics of medical care. American Economic Review, 53(5), 941-973.

Assis, M. M. A., \& Jesus, W. L. A. (2012). Acesso aos serviços de saúde: abordagens, conceitos, políticas e modelo de análise. Ciências \& Saúde Coletiva, 17(11), 2865-2875.

Barata, L. R. B., Tanaka, O. Y., \& Mendes, J. D. V. (2014). Por um processo de descentralização que consolide os princípios do Sistema Único de Saúde. Epidemiologia e Serviços de Saúde, 13(1), 15-24.

Gadelha, C. A. G. (2012). A saúde no Brasil em 2030: diretrizes para a prospecção estratégica do sistema de saúde brasileiro. Rio de Janeiro, RJ: Fiocruz/ Ipea/Ministério da Saúde/Secretaria de Assuntos Estratégicos da Presidência da República.

Gadelha, C. A. G., Quental, C., \& Fialho, B. C. (2003). Saúde e inovação: uma abordagem sistêmica das indústrias da saúde. Cadernos de Saúde Pública, 19(1), 47-59.

Giovanella, L., \& Fleury, S. (1995). Universalidade da Atenção à Saúde: acesso como categoria de análise. In C. Eibenschutz (Org.), Política de Saúde: o público e o privado (pp. 177-198). Rio de Janeiro, RJ: Fiocruz.

Grossman, M. (1972). On the concept of health capita and the demand for health. Journal of Political Economy, 80(2), 223-255.

Guerra, M., \& Gonçalves, A. O. (2014). Model of allocating public financial resources to Brazilian hospital organization that provide highly complex healthcare services. Open Medicine Journal, 1(78), 78-89.

Instituto Brasileiro de Geografia e Estatística. (2014). Estimativas da população residente no Brasil e Unidades da Federação com data de referência em $1^{\circ}$ de julho de 2014. Rio de Janeiro, RJ: IBGE. Retrieved from ftp://ftp.ibge.gov.br/Estimativas_de_ Populacao/Estimativas_2014/estimativa_dou_201 4.pdf

Malta, D. C., Moura, L., Prado, R. R., Escalante, J. C., Schimidt, M. I., \& Duncan, B. B. (2014). Mortalidade por doenças crônicas não transmissíveis no Brasil e suas regiões, 2000 a 2011. Epidemiologia, Serviço e Saúde, 23(4), 599-608.

Marchildon, G. P. (2015). The crisis of regionalization. Health Manage Forum, 28(6), 236-238.

Mello, G. A., Pereira, A. P. C. M., Uchimura, L. Y. T., Iozzi, F. L., Demarzo, M. M. P., \& Viana, A. L. d'A. (2017). O processo de regionalização do SUS: revisão sistemática. Ciência \& Saúde Coletiva, 22(4), 1291-1310.

Mendes, E. V. (2011). As redes de atenção à saúde. Brasília: Organização Pan-Americana da Saúde.

Oliver, K., Lorenc, T., \& Innvær, S. (2014). New directions in evidence-based policy research: a critical analysis of the literature. Health Research Policy and Systems, 12(34), 1-11.

Oram, B. J., Buckenham, T. M., Roake, J. A., \& Lewis, D. R. (2008). Treatment delays for patients exiting an aortic aneurysm surveillance programme. $A N Z$ Journal of Surgery, 78(3), 148-150.

Pinto, V. C., Jr., Fraga, M. N. O., \& Freitas, S. M. (2012). Análise das portarias que regulamentam a Política Nacional de Atenção Cardiovascular de Alta Complexidade. Revista Brasileira de Cirurgia Cardiovascular, 27(3), 463-468.

Portaria GM/MS n. 204, de 29 de janeiro de 2007. (2007). Regulamenta o financiamento e a transferência dos recursos federais para as ações e os serviços de saúde, na forma de blocos de financiamento, com o respectivo monitoramento e controle. Retrieved from http://bvsms.saude.gov.br/bvs/saudelegis/gm/2007/ prt0204_29_01_2007_comp.html

Portaria GM/MS n. 4.279, de 30 de dezembro de 2010. (2010). Estabelece diretrizes para a organização da Rede de Atenção à Saúde no âmbito do Sistema Único de Saúde (SUS). Retrieved from http:// bvsms.saude.gov.br/bvs/saudelegis/gm/2010/ prt4279_30_12_2010.html

Portaria SAS/MS n. 433, de 15 de maio de 2012. (2012). Suspende os parâmetros populacionais para habilitação em Média ou Alta Complexidade das áreas de Cardiologia, Oftalmologia, Nefrologia e Neurocirurgia. Retrieved from http:// bvsms.saude.gov.br/bvs/saudelegis/sas/2012/ prt0433_15_05_2012.html

Porto, S. M., Ugá, M. A. D., \& Moreira, R. S. (2011). An analysis of use of the health services by financing system: Brazil 1998-2008. Ciência \& Saúde Coletiva, 16(9), 3795-3806. 
Ribeiro, J. M., Moreira, M. R., Ouverney, A. M., \& Silva, C. M. F. P. (2017). Políticas de saúde e lacunas federativas no Brasil: uma análise da capacidade regional de provisão de serviços. Ciência \& Saúde Coletiva, 22(4), 1031-1044.

Ribeiro, J. M., \& Alcoforado, F. (2016). Mecanismos de governança e o desenho institucional da Secretaria de Saúde do Município do Rio de Janeiro (RJ). Ciência \& Saúde Coletiva, 21(5), 1339-1349.

Romano, C. M. C., \& Scatena, J. H. G. (2014). A relação público - privada no SUS: um olhar sobre a assistência ambulatorial de média e alta complexidade na região de saúde da Baixada Cuiabana em Mato Grosso. Revista de Administração Pública, 48(2), 439-458.

Santos, L. Administração pública e a gestão da saúde. (2010). In: Santos, N. R., \& Amarante, P. D.C. (Org.), Gestão pública e relação público privado na saúde (pp. 68-86). Rio de Janeiro, RJ: Cebes.

Servo, L. M. S., Piola, S. F., Paiva, A. B., \& Ribeiro, J. A. (2011). Financiamento e gasto público de saúde: histórico e tendências. In: C. Melamed, \& S. F. Piola (Orgs.), Políticas Públicas e Financiamento Federal do Sistema Único de Saúde (pp. 85-108). Brasília, DF: Ipea.

Solla, J. J. S. P., \& Chioro, A. A. R. (2014). Atenção Ambulatorial Especializada. In L. Giovanella (Org.), Políticas e Sistemas de Saúde no Brasil (2a ed., pp. 547-576). Rio de Janeiro, RJ: Fiocruz.

Travassos, C., \& Martins, M. (2004). Uma revisão sobre os conceitos de acesso e utilização de serviços de saúde. Cadernos de Saúde Pública, 20(Sup. 2), S190-S198.

Turnbull, R. G., Taylor, D. C., Hsiang, Y. N., Salvian, A. J., Nanji, S., O'Hanley, G., Doyle, D. L., \& Fry, P. D. (2000). Assessment of patient waiting times for vascular surgery. Canadian Journal of Surgery, 43(2), 105-111.

Ugá, M. A. D., Porto, S. M., \& Piola, S. F. (2014). Financiamento e Alocação de Recursos em Saúde no Brasil. In: L. Giovanella (Org.), Políticas e Sistemas de Saúde no Brasil (2a ed., pp. 395-426). Rio de Janeiro, RJ: Fiocruz.

\section{Petter Ricardo de Oliveira}

https://orcid.org/0000-0002-1224-4286

Master in Collective Health from the University of Brasília (UnB).E-mail: petterpro@yahoo.com.br

\section{Mariana Guerra}

https://orcid.org/0000-0001-5234-5172

$\mathrm{PhD}$ in Administration from the University of Brasília (UnB); Adjunct Professor in the Department of Accounting and Actuarial Sciences and the Postgraduate Program in Accounting at the University of Brasília (PPGCont / UnB). E-mail: profamarianaguerra@gmail.com

\section{Adalmir de Oliveira Gomes}

https://orcid.org/0000-0001-9000-3296

Doctor and Master in Business Administration from the University of Brasília (UnB); Adjunct Professor of the Administration Department and the Postgraduate Program in Administration of the University of Brasília (PPGA / UnB).E-mail: adalmirdeoliveira@gmail.com

\section{Aiane Luiz Martins}

https://orcid.org/0000-0003-3082-6180

Master of Science in Accounting from the Post-Graduate Program in Accounting Sciences of the University of Brasília (UnB); Professor at the Euro-American Institute of Education, Science and Technology (EUROAM). E-mail: aiane.martins@unieuro.com.br 